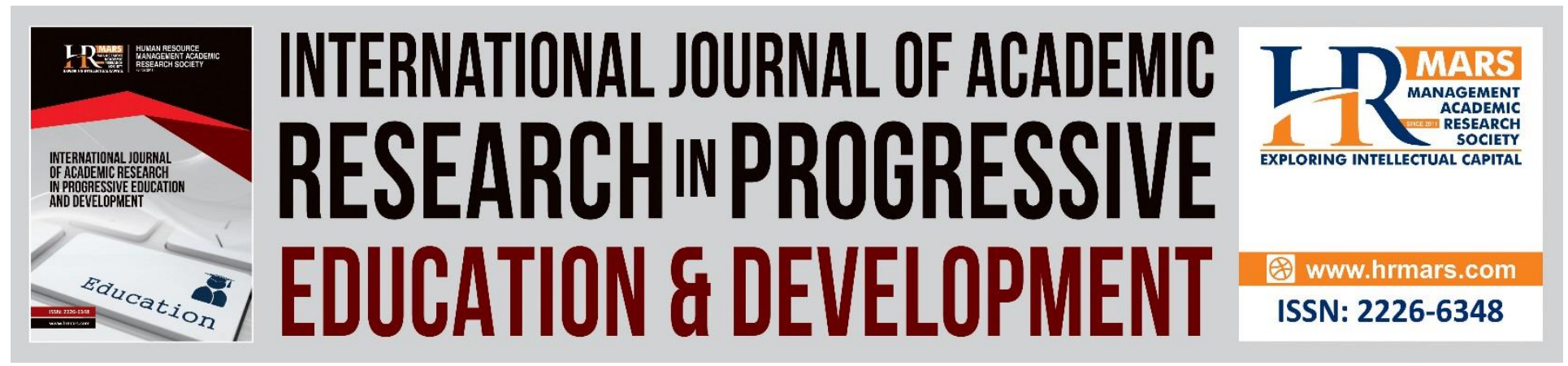

\title{
Role of Drama Skills in Regulating Students' Behaviour in Secondary Schools in Central Region, Kenya
}

Wambugu Pachomius, Zachary Njagi Ndwiga, Rebecca Wachira

To Link this Article: http://dx.doi.org/10.6007/IJARPED/v9-i2/7617

DOI:10.6007/IJARPED/v9-i2/7617

Received: 10 May 2020, Revised: 29 May 2020, Accepted: 21 June 2020

Published Online: 30 July 2020

In-Text Citation: (Pachomius, Ndwiga, \& Wachira, 2020)

To Cite this Article: Pachomius, W., Ndwiga, Z. N., \& Wachira, R. (2020). Role of Drama Skills in Regulating Students' Behaviour in Secondary Schools in Central Region, Kenya. International Journal of Academic

Research in Progressive Education and Development. 9(2), 613-631.

Copyright: (C) 2020 The Author(s)

Published by Human Resource Management Academic Research Society (www.hrmars.com)

This article is published under the Creative Commons Attribution (CC BY 4.0) license. Anyone may reproduce, distribute, translate and create derivative works of this article (for both commercial and non-commercial purposes), subject to full attribution to the original publication and authors. The full terms of this license may be seen

at: http://creativecommons.org/licences/by/4.0/legalcode

Vol. 9(2) 2020, Pg. 613 - 631

http://hrmars.com/index.php/pages/detail/IJARPED

JOURNAL HOMEPAGE

Full Terms \& Conditions of access and use can be found at http://hrmars.com/index.php/pages/detail/publication-ethics 


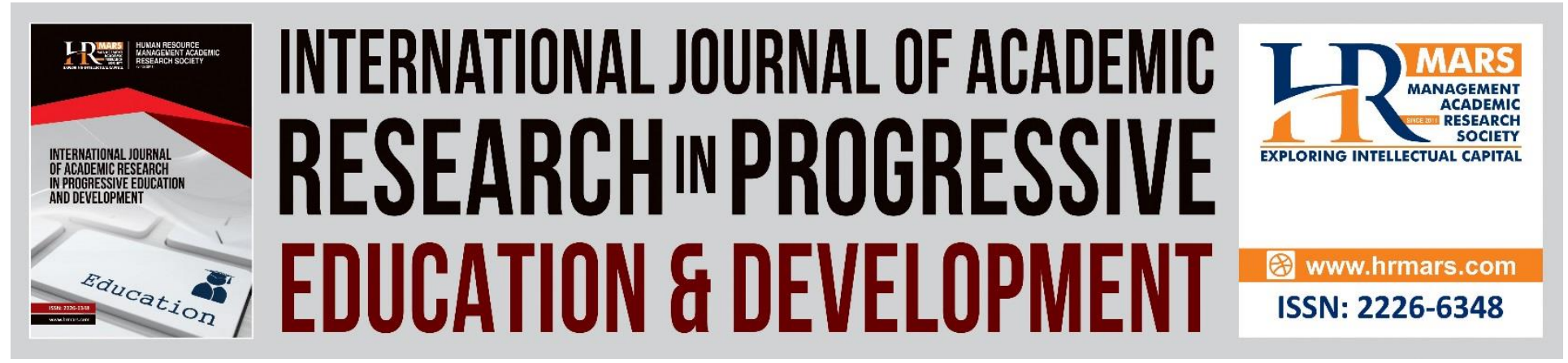

\title{
Role of Drama Skills in Regulating Students' Behaviour in Secondary Schools in Central Region, Kenya
}

\author{
Wambugu Pachomius \\ PhD Candidate, Kenya Methodist University \\ Dr. Zachary Njagi Ndwiga \\ Department of Education, University of Embu \\ Dr. Rebecca Wachira
}

Department of Theology, Religious Studies and Counselling, Kenya Methodist University

\begin{abstract}
Discipline among students is very important to their academic performance and, therefore, management of discipline in the learning environment is vital for better learning outcomes. In the recent past, inculcating discipline among students has been the subject of debate among scholars with some suggesting that disciplinary policies simply do not have different effects and that they do not prevent students' future misbehaviour. As an alternative route to discipline management, involving students in performing arts such as drama activities has been assumed to lead to better disciplinary outcomes. However, this has not been determined in the context of secondary schools in Kenya. The purpose of the study, therefore, was to determine effectiveness of drama skills strategy in regulating students' behaviour in secondary schools in Central Region, Kenya. The study was guided by Canter's Assertive Model. The study used descriptive survey design. The target population was 83 deputy principals, 79 drama teachers, and 1888 both drama and non-drama secondary school students in Central Region, Kenya. Stratified sampling was used to get a representative sample size of students. Data was collected from the respondents using questionnaires. Pretesting of instruments was done in schools from Laikipia County. The study used both qualitative and quantitative methods. The quantitative data was analysed using descriptive and inferential statistical techniques with the aid of Statistical Package for Social Scientists (SPSS) and then interpreted and discussed. The study found that the relationship between drama skills regulating and students' behaviour in secondary schools in Central Region, Kenya was statistically significant. The study therefore recommends that; there is need to encourage and support drama activities in all learning institutions. Finally, school administrators should encourage public speaking through social and academic forums.
\end{abstract}


INTERNATIONAL JOURNAL OF ACADEMIC RESEARCH IN PROGRESSIVE EDUCATION AND

DEVELOPMENT

Vol. 9, No. 2, 2020, E-ISSN: 2226-6348 @ 2020 HRMARS

Keywords: Drama Skills, Management of Discipline, Performing Arts, Students' Behaviour.

\section{Introduction \\ Background}

Discipline is an important component of human behaviour and to the functioning of organizations such as learning institutions as a whole. It is acknowledged that without discipline, both individual and organizational goals can hardly be achieved (Ouma, Simatwa, \& Serem, 2013). In the context of a school system, discipline is widely acknowledged to be essential for creating a positive school climate conducive to sound academic performance (Masitsa, 2008). It is a basic requirement for successful teaching and learning in schools and a subject of concern for teachers (Eshetu, 2014). A disciplined student is one whose behaviours and actions conform to the predetermined rules and regulations of the school (Ali, Dada, Isiaka, \& Salmon, 2014). However, discipline ideally means more than adhering to rules and regulations and entails the learner's ability to discern what is right or wrong in terms of his/her conduct (Gitome, Katola, \& Nyabwari, 2013). In contrast, indiscipline is the degeneration of human behavior and conduct and the intentional refusal to follow rules and regulations of a given society (Okumu, 2014). Indiscipline in schools has always been a major concern for teachers and educators, especially when there has been an indication that the problem is getting worse rather than improving (Tan \& Yuanshan, 2014). Students' misconduct in the classroom interferes with teaching and learning and is thought to be precursor to school dropout and similar negative social outcomes (Alemayehu, 2012; Oluremi, 2013). It is a problem that is not just deeply rooted in Kenyan schools, in schools across the continent and internationally.

Students' indiscipline in high schools is still a major concern for stakeholders in the US and England, where students reportedly still engage in malevolent behaviour (Dalporto, 2013;). Overall the evidence suggests that some forms of behaviour are very common, particularly disruptive behaviour, offensive language, bullying and other forms of aggression (Boxford, 2013; Lacoe \& Steinberg, 2018; Tamone, 2018). Indiscipline in school manifested in the form of violence has been reported in High schools in across Europe, for example, Germany (Jantzer, V et al., 2015), France (Blaya, 2012), and Portugal (Vaz, 2020). School violence and bullying in China has become a national concern recently in China (Han, Zhang \& Zhang, 2017). There are also growing concerns regarding indiscipline in secondary schools within the United Arab Emirates especially with regard to bullying and violence among students (Alomosh et al., 2019). According to Cheruvalath and Tripathi (2015) the standards of discipline were reported to be deteriorating in Indian secondary schools. Indiscipline among secondary school students in Nigeria is still high (Ali, Dada, Isiaka\& Salmon, 2014). In Ghana, Gyan et al., (2015) reports that almost all the Secondary schools face disciplinary problems and this has been the concern of all and sundry with this being attributed to students individual characteristics and the school context.

In Kenya, student discipline and unrests in secondary schools is still a serious problem and several learning institutions have been facing increasing cases of student unrest (Cooper, 2014). Many students today especially those in secondary school exhibit various forms of indiscipline in form of juvenile delinquency. However, there have been very serious cases of indiscipline in the country's secondary schools such as violence and destruction of property including arson (Okumu, 2014). This has been brought about by students' behavioural character of inconsistency 
and change of attitude to the management (Aute, 2019). Central Kenya regions is one of the most affected regions in the country by serious cases of indiscipline among secondary school students. Kimotho, Njoka and Gitimu (2019) observed that, incidents of indiscipline among learners such as bullying, assault, arson attacks, fighting, theft, vandalism, destruction of school property, rape and loss of lives, among others continue to ravage public secondary schools in the region. For instance, in Nyandarua County, a dormitory in Kitogo secondary school was burnt on $1{ }^{\text {st }}$ April 2014 leading to the closure of the school (DEO, Nyandarua South District, 2014). In Nyeri County, absenteeism/ truancy, not finishing homework, use of foul, lying are reportedly very prevalent in their schools or classes. Other common forms of indiscipline including late coming, bullying, stealing, noisemaking, fighting, vandalism and indecency are less prevalent (Kagoiya and Kegema 2018; Nyeri County district quality assurance and standards officer (DQASO), 2018). The other two counties in the region, that is Kiambu and Murang' a counties have similarly been affected. The banning of corporal punishment in schools in the Year 2001 has also generated considerable debate over its utilitarian value in instilling discipline among secondary school students. However, both proponents and opponents agreed that there should be no vacuum in the management of discipline (Okone, 2016). As such, the search for effective methods of student discipline management especially in secondary schools where the problem of indiscipline is rampant has been gaining considerable traction over the last two decades. For example, Wangai Report (2001) recommended guidance and counselling as an alternative to traditional methods while the Kenya Institute of Education (KIE) (2006) rooted for Life skills education. The Kenya National Assembly (KNA) (2008), however, advocated for school- based families. All these new concepts were adopted by the ministry of Education as the positive methods of arresting indiscipline advocated by the modern scheme of discipline. However, the role of drama on student behaviour has not been investigated in the context of secondary schools in Kenya.

\section{Drama and Management of Discipline in Secondary Schools in Kenya}

Drama is the specific mode of fiction represented in performance: a play, opera, mime, ballet, etc., performed in a theatre, or on radio or television (Emunah, 2019). Wasambo (2014) says that drama is traced back to the times of prehistoric and Stone Age periods during the early man era. Ajjawi (2018) argues that drama is particularly useful in answering philosophical questions. It allows children to take on a character and this makes them explore a perspective different from their own. Thinking for oneself should therefore be encouraged. They persist that a society full of creative thinkers will not result in a rebellion, non-conformist lawless group of people but one that is rational and intelligent with people who can truly make democratic decisions full of ethics. Drama skills are students' capacities developed as a result of their engagement in drama activities (Wizig, 2009). In drama, there are responsibilities and skills that are allocated and instilled to students. The responsibilities and skills are meant to inculcate responsible behavior in students (Mast \& Hall, 2018). For instance, Buchanan (2010); Ndagire (2012) expound that drama encompasses objective moulding, strengthening, consultation, correcting, over sighting, role modelling, perfecting and effective leadership. Ndagire (2012) also argues that management of students' discipline uses rational, objective and practical approach to issues related to discipline. Drama provides such objectivity to the participants. However, the responsibilities and skills learnt in drama in question remained unknown to many stakeholders especially in terms of regulation 
of student behavior beyond the drama settings into the wider school context. Therefore, drama skills being an integral development in the drama participation process, it was important to determine their effect on inculcating discipline among secondary school students.

\section{Statement of the Problem}

Secondary schools in Central Kenya have had to contend with student behavioural challenges characterized by serious cases of indiscipline over the last two decades, and numerous serious cases of indiscipline have been reported (Waithaka, 2017; Kagema \& Kagoiya, 2018; Ruirie, 2018; Wambugu, 2019). Kimotho et al., (2019) further observed that despite the existence of guidance and counseling services in public secondary schools in the region, incidents of indiscipline among learners such as bullying, assault, arson attacks, fighting, theft, vandalism, destruction of school property, rape and loss of lives, among others continue to ravage schools. These developments were suspected to be occasioned by lack of an effective alternative approach that is efficient in addressing the concerns and needs, real or imagined of learners while at school. Consequently, there was need for the stakeholders in the secondary education in the Region and the country at large to continually device and implement alternative strategies for management of student behavior. Drama participation has been linked to positive student behavioral outcomes in several contexts (Lipman, 2002; Philip, 2016; Irving, 2018). However, components of drama such as the skills learnt in the process have not been examined for their implications on regulating student behavior. Secondary schools from Central region in Kenya are known as formidable competitors in the Kenya National Drama Festivals (KNDF) competing successfully at every stage of the competitions over the years. Therefore, the present study sought to closely examine the role of drama skills in regulating student behaviour in secondary schools in the Region.

\section{Objective of the Study}

The study, therefore, was guided by the objective;

i) To establish the role of drama skills in regulating students' behaviour in secondary schools in Central Region, Kenya.

\section{Literature Review}

\section{Theoretical Framework}

This study was guided by the Skill Acquisition Theory.

\section{Skill Acquisition Theory}

The scientific roots of Skill Acquisition Theory can be found in different branches of psychology, which ranges from behaviourism to cognitivism and connectionism (Dekeyser \& Criado, 2013). This theory draws on Anderson's Adaptive Control of Thought (ACT) model which itself is a kind of cognitive stimulus-response theory (Ellis \& Shintani, 2013). As mentioned by Parziale and Fischer (2009), it is a neo-Piagetian theory that amalgamates elements of both cognitive and behavioristic theories. The basic claim of Skill Acquisition Theory, according to Dekeyser (2007b), "is that the learning of a wide variety of skills shows a remarkable similarity in development from initial representation of knowledge through initial changes in behaviour to eventual fluent, spontaneous, largely effortless, and highly skilled behaviour, and that this set of phenomena can 
be accounted for by a set of basic principles common to acquisition of all skills" (p. 97). In sum, as mentioned by Speelman (2005), skill acquisition can be considered as a specific form of learning, where learning has been defined as "the representation of information in memory concerning some environmental or cognitive event" (p. 26). Therefore, according to him, skill acquisition is a form of learning where "skilled behaviours can become routinized and even automatic under some conditions" (p.26). In drama, a number of skills can be leant by the participant that can change his/her behaviour for the better as he/she becomes more skilled. Such skills include; accuracy, internalization, memorization, completeness, socialization and public speaking. The Skill Acquisition Theory was, therefore, instrumental in providing insight into the impact of skill acquisition in drama on behavioural change of students in secondary schools in Central Kenya.

\section{Drama Skills for Regulating Students' Behaviour}

Drama and its associated skills sets have been investigated and argued by various scholars as applicable in the management and regulating students' discipline. Redington (1983) saw the need to play as a crucial development process in a student. According to him educationists had given a lot of attention to the use of drama in education. Values of drama activities were outlined as: releasing imagination and energy; fostering social, intellectual and linguistic development of a student; motivating learners, creating a sense of responsibility and cooperation among students. Efforts at investigating the relationship between drama skills and student behaviour had been done by Gottfredson and Gottfredson (1985), researchers from Johns Hopkins University who studied 600 secondary schools and analysed data on characteristics that were associated with discipline. They found out that school rules, observance to the daily routine, teachers and administration responses, teacher - administration relationship and inspection of students from teachers were important determinants of discipline. A study by Smith and Herring (1993) who found out that drama provides students with background knowledge and general reading skills and, most importantly, with more positive attitudes toward learning. The findings were subsequently supported by Albert and Foil (2003) who illustrated how to effectively facilitate new learning activities with dramatic techniques. In the KNDF, students imitate through impersonation. They discipline themselves in line with specific roles assigned to them. The roles assigned to characters on stage calls for self-supervision in the perfection of theatrical habits (Wasambo (2014). The new habits acquired on stage were assumed to either positively or negatively interfere with the management of the students' discipline in school depending on specific skills portrayed by different characters. In line with KNDF (2018) guidelines, several skills are manifested by students during performance on stage. A brief discussion of drama skills; accuracy, internalization, memorization, completeness, socialization and public speaking follows.

\section{Accuracy, Internalization and Memorization}

Accuracy refers to the quality of being correct or state of being precise in description of an idea (Link, 2016). Drama calls for clarity in terms of delivery of themes and ideas. This skill, acquired by a performing student was assumed to create effect in his/her general communication and thus regulating his/her behaviour. Another example of a skill that is easily acquired in drama is internalization. This is the process of making something internal (Sacit et al, 2017). Sacit posits 
that through this skill, a performer will be in a position to directly involve the integration of attitudes, values, standards and opinions of others and bringing it to one's self sense. A student can internalize behaviour and act accordingly after undertaking his/her role in any given drama genre. Memorization is the process of putting something in to one's memory (Link, 2016). This is the process of learning something by heart. Through this skill, this study assumed that students would be in a position to put in memory all that was required in the school set up and thus making them stick fully in the school environment without coercion.

\section{Completeness, Socialization and Public Speaking}

Completeness is yet another drama skill. Dramatic monologue must at some point give way to logical completeness. In drama there must be complete action (Philip, 2016). This is the skill portraying the state of having all the required parts in an entity. Drama instils completeness aspect to the performers. There was the assumption therefore that this skill would be applicable in the school set up for example completion of assignments given among others. There is the skill of socialization. Irving (2018) argues that it the process of learning to have a behaviour which is accepted by others in the community. Irvin further says that it is the process of internalizing norms and ideologies expected by the society. Through drama, students would therefore be in a position to accommodate others, and thus be able to live within the expected levels of behaviour of an institution. Irvin has also emphasized on the skill of timeliness. Through this skill, the drama students would be expected to have a sense of working within the given duration or parameters. Additionally, public speaking skills can also be accrued from drama activities. This has been illustrated by Crumpler and Schneider (2002) who argue that students who have been involved in dramatic activities are less likely to have difficulty speaking in public, will be more persuasive in their communications, both written and oral, will be able to put themselves into others' shoes and relate to them, and will have a more positive, confident self-image. According to Nathan (2017), public speaking is performance itself in the auditorium or in front of others. He continues and says that public speaking is a performing art. It seeks to educate students in a method that directs the power of spoken word towards end of useful life.

\section{Problem Solving and Organizational Skills}

Problem solving skills is another form of skills set that had been advanced by scholars. According to Elizabethan and Jacobean (2008), dramatic arts education is an important means of stimulating creativity in problem solving. Albert and Foil (2003) asserts that a student can become another person, explore a new role, try out and experiment with various personal choices and solutions to very real problems from their own life, or problems faced by characters in literature or historical figures. This could be the most important reason for drama in schools. Kava Cultural Group Association (n.d) had done research on importance of drama where the research compared those who regularly participate in educational theatre and drama activities and those peers who had not been participating in any theatre and drama programs. It was noted that those engaged in theatre and drama felt that they were creative, like going to school more, enjoyed school activities more, were better at problem solving and that they were better at coping with stress. Additionally, drama could also be used to instil organizational skills among students. Halliwell (1987) in the translation of Aristotle's The Poetics of Aristotle has given the Aristolian 
elements of drama as plot, character, thought, diction, spectacle and song. This is the philosophy that forms the base of the story or a moral lesson that characters learn (Philip, 2016). The study assumed that these themes form the basis and character change of behaviour.

\section{Drama Skills and Management of Discipline}

Drama skills have also been viewed as a crucial tool for managing the personal discipline. This can be illustrated by Wasambo (2014) who argues that drama has been in the past associated with how man manages himself or herself discipline wise since it has a long history of influence. Moreover, drama is also seen as a critical avenue of instilling skills to the learner. This view had been supported by Gardener (2003) who argued that drama is effective because it taps different intelligences possessed by students to help them learn and realize success in academic situations and at the same time in their life. He goes on and states that drama is an effective means of utilizing one's intrapersonal and interpersonal intelligences, dealing with how individuals understand the way they think, interact and act, and therefore effectively influencing their behaviour. Additionally, incorporating drama into curriculum instructions is seen as effective because it will help the students who are weak (Gardner, 2003). As drama skills help in regulating students' behavior, there was need to emphasis on the transferability of such skills. This had been supported by Lipman (2002) who posits that the skills learnt are always transferrable to everyday life. On the basis of this background, the study proposed to establish the extent that drama affected the behaviour of students with regards to the management of discipline in secondary schools.

\section{Methodology \\ Research Philosophy and Design}

The present study was grounded on a positivist philosophy. The positivist paradigm is also called the scientific paradigm. The purpose of research in this paradigm is to prove or disprove an existing assumption (Žukauskas, Vveinhardt \& Andriukaitienė, 2018). The positivist approach was adopted due to the level of inquiry and the empirical rigour using both qualitative and quantitative methods demanded to satisfy the inquiry. The positivist approach in this study was used to validate or invalidate assumptions on the influence of drama participation constructs on the management of discipline among secondary school students. Positivism stresses the importance of quantifying research through large scale surveys in order to get an overview of the whole and uncover social trends (Žukauskas, Vveinhardt \& Andriukaitienè, 2018). This enables the testing of laws or theories against systematically collected data. In the present study, assumptions made on drama participation as a viable method of discipline management was tested against data collected from secondary schools which participate in drama festivals in Central Region of Kenya. In line with this, descriptive survey design was used in the study. A descriptive survey attempts to describe or document current conditions or attitudes (Wimmer \& Dominick, 2014). The design was appropriate in the sense that the study was geared towards determining the extent to which the discipline of students was influenced by drama skills and how this affected the management of students' discipline by the school administration. Through descriptive research design, drama students behaviour was examined along the drama skills learnt. 
INTERNATIONAL JOURNAL OF ACADEMIC RESEARCH IN PROGRESSIVE EDUCATION AND DEVELOPMENT

Vol. 9, No. 2, 2020, E-ISSN: $2226-6348 @ 2020$ HRMARS

\section{Location of Study}

The study was carried out in Central Region, Kenya. The Central Kenya region consists of the five counties constituting the former central province of the Republic of Kenya, namely; Murang'a, Nyeri, Kiambu, Nyandarua, and Kirinyaga. According to Regional Coordinator Education's Office (2017), the region has a total of 902 secondary schools. The region's teacher to student ratio is 1:22 for public high schools. According to statistics obtained from Drama secretariats in the five counties (2017), 400 secondary schools in the region took part in drama festival at the sub county levels (Central Region Education Headquarters, 2018) indicating that there was considerable engagement in drama by the schools in the region. Further, public secondary schools in Central region are diverse in terms of students and teacher population and can be taken as being representative of the entire country.

\section{Target Population of the Study}

This study targeted 79 public secondary schools in the region that have consistently participated in the Kenya National Drama Festival competitions up to the sub county levels and beyond in the last five years. From these, the accessible population comprised of 79 deputy principals (some secondary schools had more than one deputy principal); 79 drama teachers, and; 1888 dram students and non-drama students. The students were drawn from form two, three and four in secondary schools due to the fact that they had considerable experience in high school drama and student life and could give informed conclusions on the study questions. Form one students are new in school and therefore were not effectively involved.

\section{Sampling techniques and Sample Size}

The census method was also used to select all the 79 secondary schools that had participated in the Kenya National Drama Festival competitions up to the sub county levels and beyond in the last five years. This was informed by the fact that the population of schools was small and accessible. For the accessible population of deputy principals, drama teachers and drama students, the sample size was determined via the formula supplied by Kathuri and Pals (1993), thus;

$$
n=\frac{\chi^{2} N p q}{\sigma^{2}(N-1)+\chi^{2} p q}
$$

Where; $\mathrm{n}=$ required sample size, $\mathrm{N}=2046$ is the given population size of the drama students, deputy principals and drama teachers, $P=$ population proportion, assumed to be $0.5, \mathrm{q}=1-p=$ $0.5, \sigma^{2}=$ the degree of accuracy whose value is 0.05 and $\chi^{2}=$ table value of chi-square for one degree of freedom, which is 3.841. Substituting this into the formula yielded a sample of 324 respondents. To this sample size was added 100 non-drama students bringing the entire sample size to 419 respondents. The deputy principals and drama teachers were selected using the census method while the drama students and non-drama students were selected through systematic random sampling. 


\section{Data Collection Instruments}

The study used questionnaires and document analysis to collect data for the study. Questionnaires with five-point Licket scales were used to collect data on drama and discipline management of the selected students. The use of questionnaires was informed by the fact that the study was a survey involving a large number of respondents who also could not be available for in-depth interviews when the schools were in session. Secondary information was obtained from documents from drama secretariat offices and from the public secondary schools across the Central Region of Kenya. The data questionnaires were pilot tested in order to establish validity and reliability before they were finally used in collection of data. The pilot data results were analysed in order to assure clarity.

\section{Data Analysis}

Statistical Package for Social Scientists (SPSS) version 22.0 was used to conduct data analysis using simple descriptive statistical measures, such as, peercentages, means and standard deviations to give glimpse of the general trend. Additionally, inferential statistics involving both correlation and multiple regression was conducted to determine associations between the dependent variable and the independent variable, as under;

$$
\mathrm{Y}=\mathrm{B}_{0}+\mathrm{B}_{2} \mathrm{X}_{2}+\mathrm{e}
$$

Where, $Y=$ Management of students' discipline, $B_{0}=$ Constant, $B_{2}=$ Change in $Y, X_{2}=$ Drama skills and $\mathrm{e}=$ error

\section{Results and Discussion Introduction}

The researcher administered 424 questionnaires to all the sampled respondents for this study. Out of these, a total of 335 questionnaires were returned correctly filled and useable for the study. Correspondingly, 57 deputy principals, 54 drama teachers, 143 drama students and 81 non-drama students returned their completed instruments. The overall response rate to the questionnaires was, thus, 79\% which was high and, therefore, acceptable for the study (Babbie, 2004).

\section{Drama Skills on Students' Behaviour}

The objective of the study was to examine the influence of drama skills on regulating students' behaviour secondary school students in Central Region, Kenya. This variable was described in terms of; accuracy, internalization, memorization, completeness, socialization, problem solving and organizational skills. The results are presented and discussed as follows. 
INTERNATIONAL JOURNAL OF ACADEMIC RESEARCH IN PROGRESSIVE EDUCATION AND

DEVELOPMENT

Vol. 9, No. 2, 2020, E-ISSN: $2226-6348$ @ 2020 HRMARS

Table 1

Drama Skills on Students' Behaviour

\begin{tabular}{lllllllll}
\hline Drama Skill & Respondent & SD & D & N & A & SA & Mean & Std.Dev \\
\hline Accuracy & Deputies & 4.5 & 9.1 & 22.7 & 45.5 & 18.2 & 3.64 & 1.036 \\
& Drama Teachers & 0 & 0 & 26.7 & 53.3 & 20 & 3.93 & 0.704 \\
& Drama Students & 9.1 & 8.4 & 25.2 & 29.4 & 28 & 3.59 & 1.235 \\
& Non-Drama Students & 5.5 & 3.6 & 36.4 & 32.7 & 21.8 & 3.62 & 1.045 \\
\hline Internalization & Deputies & 0 & 9.1 & 22.7 & 50 & 18.2 & 3.77 & 0.859 \\
& Drama Teachers & 0 & 0 & 26.7 & 53.3 & 20 & 3.93 & 0.704 \\
& Drama Students & 10.5 & 9.1 & 26.6 & 31.5 & 22.4 & 3.46 & 1.232 \\
& Non-Drama Students & 7.3 & 7.3 & 23.6 & 32.7 & 29.1 & 3.69 & 1.184 \\
\hline Memorization & Deputies & 0 & 9.1 & 36.4 & 36.4 & 18.2 & 3.64 & 0.892 \\
& Drama Teachers & 0 & 6.7 & 20 & 60 & 13.3 & 3.8 & 0.775 \\
& Drama Students & 14.7 & 7.7 & 18.9 & 25.9 & 32.9 & 3.55 & 1.398 \\
& Non-Drama Students & 10.9 & 9.1 & 32.7 & 20 & 27.3 & 3.44 & 1.288 \\
\hline \multirow{2}{*}{ Completeness } & Deputies & 0 & 9.1 & 27.3 & 45.5 & 18.2 & 3.73 & 0.872 \\
& Drama Teachers & 0 & 6.7 & 26.7 & 40 & 26.7 & 3.87 & 0.915 \\
& Drama Students & 7.7 & 9.8 & 20.3 & 28.7 & 33.6 & 3.71 & 1.244 \\
& Non-Drama Students & 5.5 & 5.5 & 18.2 & 25.5 & 45.5 & 4 & 1.171 \\
\hline Socialization & Deputies & 0 & 4.5 & 27.3 & 31.8 & 36.4 & 3.95 & 1.033 \\
& Drama Teachers & 0 & 0 & 33.3 & 33.3 & 33.3 & 4 & 0.845 \\
& Drama Students & 4.2 & 6.3 & 14 & 26.6 & 49 & 4.1 & 1.122 \\
& Non-Drama Students & 14.5 & 3.6 & 25.5 & 14.5 & 41.8 & 3.65 & 1.43 \\
\hline Public & Deputies & & 9.1 & 22.7 & 36.4 & 31.8 & 3.91 & 0.96 \\
& Drama Teachers & & & 6.6 & 46.7 & 46.7 & 4.4 & 0.632 \\
& Drama Students & 7.7 & 3.5 & 15.4 & 21.7 & 51.7 & 4.06 & 1.229 \\
& Non-Drama Students & 5.5 & 3.6 & 32.7 & 25.5 & 32.7 & 3.76 & 1.122 \\
\hline
\end{tabular}

Key: SD = Strongly Disagree; D=Disagree; $N$ = Neutral; $A=$ Agree; $S A$ = Strongly Agree; and \% = Percentages

Accuracy as a drama skill on regulating students' behaviour

Accuracy refers to the quality of being correct or state of being precise in description of an idea (Link, 2016). The findings in Table 1 suggests that most (45.5\%) of the deputy principals and drama teachers (53.3\%) agreed with the role of accuracy as a drama skill on instilling a sense of discipline among students. Most drama students (28\%) and non-drams students (21.8\%) also tended to strongly agree with the view of accuracy as a drama skill in inculcating discipline among students while most non-drama students were uncertain on the importance of this skill in improving discipline among students. Kozulin et al., (2003) advocate for the application of various skills learnt in drama such as a sense of accuracy among the students and teachers in order to realize school discipline management. 
Internalization as a drama skill on regulating students behaviour According to Wizig (2009), internalization occurs when a participant has the ability to both master and value new practices and ways of thinking regardless of external incentives or penalties. The results in Table 1 indicates that majority (50\%) of the deputy principals agreed that Internalization as a drama skillwas important in instilling a sense of discipline among secondary school students. Most drama teachers (53.3\%) also agreed with this view. However, there was low agreement among the drama students (31.5\%) and the and non-drama students $(32.7 \%)$ on the role of internalization as a drama skill on instilling discipline among secondary school students. Therefore, the implication for the findings is that most respondents were supportive of the view that internalization as a drama skillwas instrumental in the management of discipline among secondary school students in Central Region, Kenya. This was consistent with the views of McMaster 1998 (as cited in Kariuki \& Humprey, 2006) and also Wizig (2009) who observed that drama also helps engage students in meaningful communication and provides the interaction they need to effectively internalize new knowledge.

\section{Memorization as a drama skill on regulating students' behaviour}

Memorization is the process of putting something in to one's memory (Sangster, 2012). Specifically, there was uncertainty (36.4\%) among the deputy principals agreed with this statement which was, however, agreed with by most (60\%) of the drama teachers. Most of the drama students tended to strongly agree (32.9\%) that memorization as a drama skill inculcated a discipline among secondary school students though most of the non-drama students $(32.7 \%)$ were uncertain with the statement. These findings lead to the deduction that there was uncertainty on whether memorization as a drama skill was instrumental in the management of discipline among secondary school students. These findings disagree with Kozulin et al., (2003) who advocated for drama internalization skills in the management of student discipline. They also disagree with Sangster (2012) who found that students enhanced memorization ability developed through the arts were encouraging their academic performance and hence their discipline.

\section{Completeness as a drama skill on regulating students behaviour}

Completeness is the quality of being whole or perfect and having nothing missing. In drama there must be complete action and, as a result, drama instils completeness aspect to the performers (Philip, 2016). In the present study, most (45.5\%) of the deputy principals and drama teachers (40\%) agreed with this statement while most of the non-drama students $(45.5 \%)$ and drama students (33.6\%) strongly agreed with the statement. As such, it can be implied that completeness learnt as a drama skill was important in inculcating disciplineamong secondary school students in Central Region, Kenya. Using survival analysis, a study by Thomas (2016) found that students who enroll and complete courses in the arts face a lower risk of dropping out compared to similar non-arts students. According to a study by Singh and Klopfenstein (2015) in the US, student enrolment in public school courses in visual art, music, theatre, and dance was linked to reduced high school dropout even after controlling for observable student and school characteristics expected to influence both arts participation and school commitment. 
Socialization as a drama skill on regulating students behaviour

Socialization is basically mixing freely with other people; it is also the process of learning to have a behaviour, norms and ideologies which are accepted by others in the community or are socially acceptable (Irving, 2018). Majority of the students were inclined to strongly support the view with more drama students (49\%) than non-drama students (41.8\%) strongly agreeing while more deputy principals (36.4\%) than drama teachers (33.3\%) strongly agreed with the view. Hence, it is evident that socialization skills as an acquired behavior in drama was regarded as instrumental in instilling a sense of discipline among secondary school students in the region. According to McCaslin (2000), creative drama facilitates social development, acceptance of self and acceptance of others, and sharing with others. Further, the socialization of participants is bound to improve and can be used to cope with problems in different circumstances (Freeman et al., 2003).

\section{Public speaking as a drama skill on regulating students behaviour}

Public speaking is the process or act of performing a speech to a live audience. Public speaking is commonly understood as formal, face-to-face, speaking of a single person to a group of listeners (German, 2010). Majority (36.4\%) of the deputy principals agreed with this statement which was also agreed with by most (46.7\%) of the drama teachers. Most of the drama students strongly agreed with the view public speaking as a drama skill on instilling a sense of discipline among secondary school students (51.7\%) of the drama students and non-drama students $(32.7 \%)$ strongly agreeing with the statement. As a result, it can be deduced that public speaking as a drama skill was important in managing discipline among secondary school students. DocanMorgan (2015) argues that competence in public speaking is paramount to student success in and out of the classroom as public speaking is a necessary part of both classroom and extraclassroom responsibilities. According to Schreiber and Hartranft (2013), we create a self-fulfilling prophecy in speech, meaning that we form an expectation and adjust our behavior to match. As a result, the expectation we created becomes true. Drama creates confident, compelling speakers whether presenting in class, on a stage in front of a large audience or in a one to one conversation every day of their lives.

\section{Effectiveness of Management of discipline in secondary schools in Central Kenya}

The study sought to determine the status of management of discipline in secondary schools in Central Kenya. This was the dependent variable and was measured in terms of alternative channel of disciplinary tools and low occurrences of indiscipline. The results are presented and discussed as follows.

\subsubsection{Alternative channel of disciplinary tools}

The respondents were asked to state whether drama participation served effectively as an alternative channel of disciplinary tools in the management of discipline among secondary school students. The findings are presented in Table 2. 
INTERNATIONAL JOURNAL OF ACADEMIC RESEARCH IN PROGRESSIVE EDUCATION AND

DEVELOPMENT

Vol. 9, No. 2, 2020, E-ISSN: $2226-6348$ @ 2020 HRMARS

Table 2: Alternative channel of disciplinary tools

\begin{tabular}{lllllllll}
\hline Respondent & $\mathrm{N}$ & 1 & 2 & 3 & 4 & 5 & Mean & Std. Dev \\
\hline Deputies & 57 & 7.1 & 64.3 & 14.3 & 7.1 & 7.1 & 2.43 & 1.016 \\
Drama Teachers & 54 & 0 & 0 & 26.7 & 26.7 & 46.7 & 4.20 & 0.862 \\
Drama Students & 143 & 3.5 & 10.5 & 25.9 & 34.3 & 25.9 & 3.69 & 1.077 \\
Non-Drama Students & 81 & 1.8 & 3.6 & 12.7 & 40 & 41.8 & 4.16 & 0.918 \\
Aggregate & 335 & & & & & & 3.62 & 0.9683 \\
\hline
\end{tabular}

According to the results in Table 2, the aggregate mean, $M=3.62 ; S D=0.968$ suggests implies that there was agreement and a low variation on whether drama participation served effectively as an alternative channel in the management of discipline among secondary school students. Specifically, majority of the drama teachers (46.7\%) strongly supported this view on drama as an alternative channel of discipline, however, majority of the deputy principals (64.3\%) did disagree with the efficacy of the drama approach as an alternative in management of discipline among students. Most of the drama students (34.3\%) agreed with the opinion that drama was an effective alternative in management of discipline which was a view shared by most of non-drama students (41.8\%) who strongly agreed with it. These findings imply that while there were differing perceptions on the efficacy of drama participation as an alternative channel in the management of discipline among secondary school students, it was still regarded as an important tool in the disciplinary efforts in secondary schools in Central Region of Kenya. These findings agreed with Etesi (2012) who found that alternative discipline management strategies were increasingly effective than the traditional discipline management strategies such as corporal punishment. The findings, however, disagree with Handayani (2015) who argued that alternative strategies that are used to inculcate discipline among students in secondary schools have proved to be ineffective.

Occurrences of indiscipline

There was need to establish the status of occurrences of indiscipline among secondary school students. The results are presented in Table 3.

Table 3: Occurrences of serious forms of indiscipline

\begin{tabular}{lllll}
\hline Type of indiscipline & None at all (\%) & Little (\%) & Much (\%) & Very Much (\%) \\
\hline Strikes & 59 & 17 & 10 & 15 \\
Bullying & 29 & 7 & 36 & 27 \\
Fighting & 50 & 11 & 26 & 14 \\
Threats to teachers & 53 & 22 & 20 & 5 \\
Vandalism & 39 & 27 & 16 & 18 \\
Theft & 15 & 26 & 19 & 40 \\
Substance abuse & 32 & 36 & 11 & 21 \\
Aggregate (\%) & 40 & 21 & 20 & 20 \\
\hline
\end{tabular}


Looking at the results in Table 9, it is evident that the occurence of serious forms of indiscipline among students were not reported as indicated by the aggregate percentage of $40 \%$ compared to those who reported their occurences were little (21\%), much (20\%) and very much (20\%). However, the results suggest that the schools still experienced considerable serious disciplinary challenges among students in terms of theft (40\%), bullying (27\%) and substance abuse (21\%). The decreasing incidences of serious forms of discipline attributable to involvement in drama suggests that as an alternative means of discipline, drama provided a means where students learnt the value of self discipline in some activity they liked participating in. This finding agrees with Were (2014) who noted that dramatic ritual and their related rules and regulations play very significant roles in the management of the community. People restrict themselves to the rules, regulations, values and beliefs of the community. By restricting themselves in these rules and regulations, people are able to discipline themselves and therefore easily managed. Were's view is further collaborated by that of Khamalwa (2004) who notes that a dramatic ritual brings change of status to the entire community. A school is an established community with laid down rules and regulations. During drama activities, there are rules that must be observed in order for the team to be well disciplined.

\section{Regression of drama skills and Regulation of Students' Behaviour}

Pearson product moment correlation coefficient test was used to investigate whether there existed a significant relationship between drama skills and regulation of students' behaviour in secondary schools in Central Region, Kenya. The analysis was tested at 0.05 level of significance. Findings are presented in Table 4.

Table 4: Regression of drama skills and Regulation of Students' Behaviour

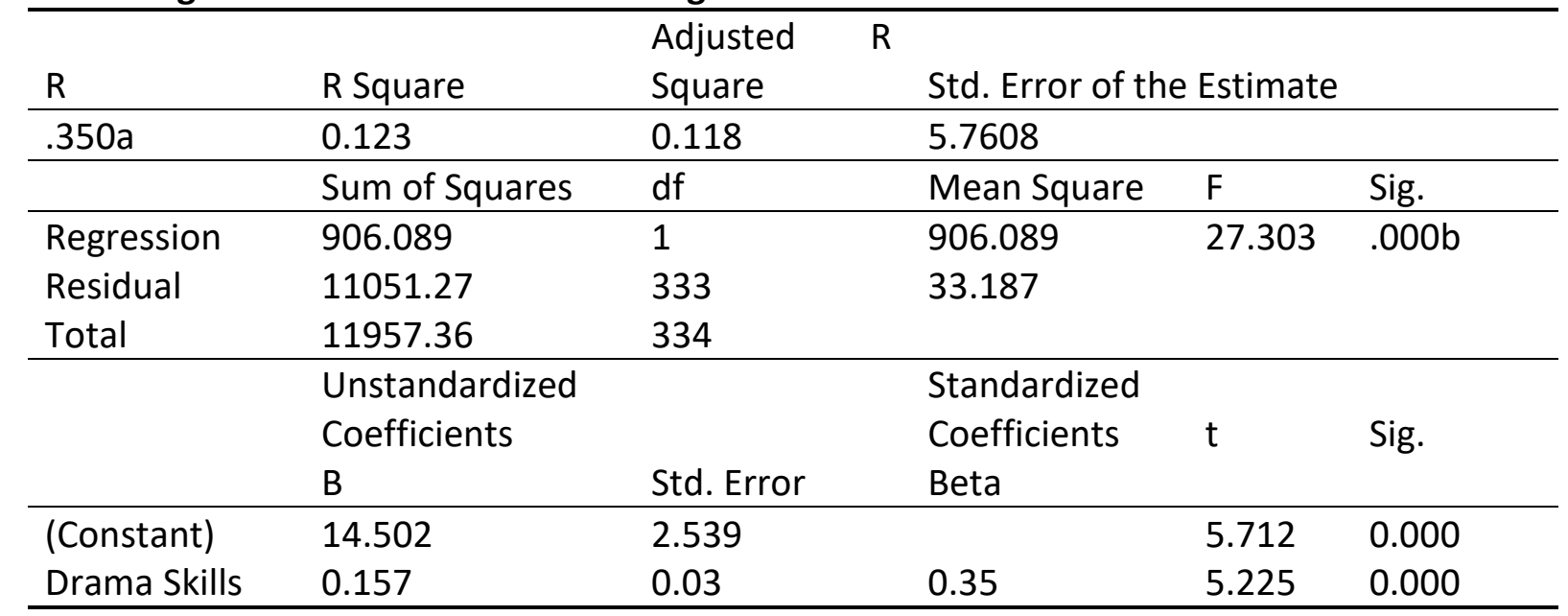

a Dependent Variable: Regulation of Students' Behaviour

b Predictors: (Constant), Drama Skills

The findings in Table 4 shows that there was indeed a significant relationship $(\beta=0.35, p=$ $0.000<p=0.05$ ) between drama skills and regulation of students' behaviour in secondary schools in Central Region, Kenya. The results suggest that there was a moderate but positive relationship between the variables indicating that as things currently stand, the development of drama skills 
was instrumental in helping students regulate their behaviour towards disciplinary issues in the schools. The $r$-square $\left(R^{2}=0.123\right)$, further, indicates that the model could explain upto $12.3 \%$ of the variations in the regulation of students' behaviour in secondary schools in Central Region. It also suggests that the model could improve when more predictive variables were incoporated into the model. Further, from the ANOVA results, it is evident that there is a significant difference between the means ofdrama skills and the mean of variable predicting regulation of students' behaviour in secondary schools in Central Region $\left(F_{o^{\prime}}=27.303>F_{c}=3.87 ; \alpha<0.05 ; d f=1,333 ; p\right.$ $=0.000<p=0.000<p=0.05)$. As such, we conclude that drama skills were important tools of regulating student behavior and could lead to improved outcomes in management of discipline insecondary schools. Therefore, the resulting model is predicted by;

Regulation of students' behaviour in secondary schools $=14.502+0.157$ Drama Skills Or simply, $\quad \mathrm{Y}=14.502+0.157 \mathrm{DS}$

This finding concurs with Kozulin et al., (2003) who indicated that the realization of school discipline management is seen as being realized depending on the ability of the stakeholders to employ drama skills towards managing instilling a sense of responsibility and discipline among the students leading scholars to advocate for the application of various skills such as memorization, internalization and sense of accuracy among the students and teachers. As drama skills influence the way students' view things, they help in regulating students' behavior, there was need to emphasis on the transferability of such skills to other domains of learningas they help them make moral decisions and understand others' points of view (Lipman, 2002).

\section{Conclusions and Recommendations Conclusions}

The study revealed that there was a significant relationship between drama skills and regulation of students' behaviour in secondary schools in Central Region, Kenya, thus, leading to the conclusion that acquisition of drama skills was an important factor in the regulation of students' behaviour. Drama skills such as internalization, completeness as well as socialization skills were rated as instrumental in behavioural regulation among students. Accuracy and public speaking were also rated as important drama skills in the regulation of students' behaviour. However, there was uncertainty on whether memorization as a drama skill was was effective in behavioural regulation among secondary school students. Therefore, the current development of drama skills was instrumental in regulation of students' behaviour towards disciplinary issues in the schools.

\section{Recommendations}

The study, therefore, recommends that there is need for drama teachers to reinforce the learning of drama skills among the students and often check whether they were indeed using the skills outside the drama settings in the wider school context. The schools' administrations should also encourage all students to participate in drama at least at some point in their secondary education cycle to enable them acquire the skills that can improve their behavior. Students with serious behavioural problems should be required to take part in drama activities. 
INTERNATIONAL JOURNAL OF ACADEMIC RESEARCH IN PROGRESSIVE EDUCATION AND

DEVELOPMENT

Vol. 9, No. 2, 2020, E-ISSN: $2226-6348$ @ 2020 HRMARS

\section{Recommendation for Further Studies}

The researcher recommends comparative study on effectiveness of music and drama in management of students discipline in secondary schools to be carried out by future researchers.

\section{References}

Alemayehu, T. M. (2012). Assessment of students' misbehavior and coping strategies (in the case of Shashemene secondary school). MA thesis; Addis Ababa University. Addis Ababa, Ethiopia.

Ali, A., Dada, I., Isiaka, G., \& Salmon, S. (2014). Types, Causes and Management of Indiscipline Acts among Secondary School Students in Shomolu Local Government Area of Lagos State. Journal of Studies in Social Sciences, 8(2), 254-287

Alomosh, A. F., Alrahoomi, S. M., Alshamsi, M. M. H., \& Alani, O. D. S. (2019). Bullying Among School Students in the UAE Society. Psychology, 9(2), 45-56.

Aute, D. A. (2019). Secure Parental Attachment and Deviant Behaviour Among Secondary School Students in Homabay County-Kenya. Science Journal of Education, 7(6), 127-133.

Boxford, S. (2013). Schools and the Problem of Crime. Routledge.

Buchanan, M. (2010). The Importance of Drama in Primary Education. Retrieved from https://www.scribd.com/document/95540286/Drama-in-Education-DIE

Cheruvalath, R., \& Tripathi, M. (2015). Secondary school teachers' perception of corporal punishment: A case study in India. The clearing House: A journal of educational strategies, issues and ideas, 88(4), 127-132.

Cooper, E. (2014). Students, arson, and protest politics in Kenya: School fires as political action. African Affairs, 113(453), 583-600.

Dalporto, D. (2013). Restorative Justice: A Different Approach to Discipline. We Are Teachers. Retrieved 1 June 2017. http://www.weareteachers.com/restorative-justice-a-differentapproach-to-discipline/

Emunah, R. (2019). Acting for real: Drama therapy process, technique, and performance. Routledge.

Eshetu, A. A. (2014). Indiscipline Problems of High School Students: The case of Ethio-Japan Hidasse Secondary School (Addis Ababa, Ethiopia). Journal of Education and Practice, 5(37), 23-28

Fuchs, M., \& Schmalz, S. (2010). Violence in schools. A Multilevel Analysis on the Impact of Upbringing in the Family and Class Composition, 30(2), 134-148.

Gardner, M., Roth, J., \& Brooks-Gunn. (2008). Adolescents' participation in organized activities and developmental success 2 and 8 years after high school: Do sponsorship, duration, and intensity matter? Developmental Psychology, 44(3), 814-830.

Gitome, J., Katola, M., \&Nyabwari, B. (2013). Correlation Between Students' Discipline and Performance in the Kenya Certificate of Secondary Education. International Journal of Education and Research 1(8)

Gottfredson, G. D., \&Gottfredson, D. C. (1985). Victimization in Schools. New York: Plenum health of elementary schools. School Psychology Quarterly, 23(4), 462-473. 
INTERNATIONAL JOURNAL OF ACADEMIC RESEARCH IN PROGRESSIVE EDUCATION AND

DEVELOPMENT

Vol. 9, No. 2, 2020, E-ISSN: $2226-6348$ @ 2020 HRMARS

Han, Z., Zhang, G., \& Zhang, H. (2017). School bullying in urban China: Prevalence and correlation with school climate. International journal of environmental research and public health, 14(10), 1116.

Jantzer, V., Haffner, J., Parzer, P., Resch, F., \& Kaess, M. (2015). Does parental monitoring moderate the relationship between bullying and adolescent nonsuicidal self-injury and suicidal behavior? A community-based self-report study of adolescents in Germany. BMC public health, 15(1), 583.

Kagema, N., \& Kagoiya, P. (2018). Examining Factors Contributing to Indiscipline in Primary Schools in Nyeri Central Sub-County, Kenya. Pedagogical Research,3(2), 07. https://doi.org/10.20897/pr/91650

Kava Cultural Group Association, (n.d). Drama Improves. Lisbon Key Competences in Education (DICE), Budapest, HU. Retrieved from http://www.dramanetwork.eu/

Kenya Institute of Education (KIE) (2006). Facilitator's handbook on Life skills education, for prevention of drugs and substance abuse. Kenya Institute of Education.

Kenya National Assembly (KNA), (2008). Report of the departmental committee on education, research and technology on the inquiry into students' unrests and strikes in secondary schools. Kenya National Assembly.

Kenya National Drama Festival. (2018). Revised Rules and Regulations. Nairobi. Ministry of Education.

Kimotho, F. W., Njoka, J. N., \& Gitumu, M. W. (2019). Effectiveness of Counselors in Managing Discipline in Public Secondary Schools in Kenya: Case of Mt. Kenya East Selected Counties. African Journal of Education, Science and Technology, 5(2), 220-228.

Lacoe, J., \& Steinberg, M. P. (2018). Rolling back zero tolerance: The effect of discipline policy reform on suspension usage and student outcomes. Peabody Journal of Education, 93(2), 207-227.

Lipman, M. (2002). Interview. Critical \& Creative Thinking: The Australasian Journal of Philosophy for Children.

Masitsa, G. (2008). Discipline and disciplinary measures in the free state Township schools: Unresolved problems. Acta Academia 40 (3), 234-270. Available ent http://reference sabinetcoza/webx/access/electronic-journals/academ/academ-v-40-n3-also-pdfAcessed, 13 December 2017.

McMaster, J. C. (1998)."Doing” Literature: Using Drama to Build Literacy. The Reading Teacher, 574-584. (EJ562451). Retrieved from https://www.jstor.org/stable/20201964

Ndagire, B. (2012). Management of Students Discipline in Private Secondary schools in Entebbe Municipality. A Dessertation directed to the Directorate of Research. Kampala. Uganda: Makerere University.

Okone, S. (2016). Analysis of The Banning Of Corporal Punishment With Specific Reference To Mill's Theory Of Utilitarianism: A Case Of Secondary Schools In Kisii Central Sub-County, Kenya. Unpublished Thesis, Egerton University

Okumu, M. O. (2014). An Investigation of Factors Influencing Indiscipline Among Students In Public Day Secondary Schools In Makadara District, Nairobi County. (Unpublished Thesis), Kenyatta University 
Oluremi, F. D. (2013).Truancy and Academic Performance of Secondary School Students in Southwestern Nigeria: Implications for Counseling. International Journal for CrossDisciplinary Subjects in Education; 3(2): 1424-1428.

Ouma, M. A., Simatwa, E. M., \&Serem, T. (2013). Management of pupil discipline in Kenya: A Case Study of Kisumu Municipality. Educational Research, 4(5), 2141-5161.

Ruirie, K. P. (2018). Efficacy of Alternative Methods of Enforcing Learners' Discipline in Primary Schools in Nyeri-Central Sub-County, Kenya (Doctoral dissertation, Karatina University).

Tamone, S. G. (2018). Teachers' ways of seeing their approaches with student behaviour in the preparatory year (Doctoral dissertation, Queensland University of Technology).

Tan, E., \& Yuansha, C. (2014). Discipline problems in schools: teachers' perception. Teaching and Learning 19(2): 1-12.

Vaz, C. E. (2020). Anti-bullying games. The perception of portuguese teachers and educators. Pedagogía Social. Revista Interuniversitaria, (35), 47-59.

Wasambo, W. (2014). A Traditional Ritual ceremony as Edurama: a case study of imbalu ritual among the Bukusu of western Kenya, Kenya: Kenyatta University

Waithaka, T. K. (2017). Department of Sociology and Social Work (Doctoral Dissertation, Department Of Sociology And Social Work Indiscipline In Public Secondary Schools: The Case Of Nairobi County (Unpublished Thesis), University Of Nairobi.

Wambugu, M. W. (2019). Chaplaincy Services and Students' Holistic Development in Anglican Church of Kenya Sponsored Secondary Schools in Mount Kenya Central Diocese, Kenya. Journal of Arts and Humanities, 8(6), 01-10. 